•论坛・

\title{
国外国家公园教育利用研究进展与启示
}

\author{
陈东军 ${ }^{1,2}$ 钟林生 ${ }^{1,2 *}$ \\ 1 (中国科学院地理科学与资源研究所, 中国科学院区域可持续发展分析与模拟重点实验室, 北京 100101) \\ 2 (中国科学院大学, 北京 100049)
}

摘要: 教育是国家公园的主要功能之一, 教育利用是国家公园的公益性和国家主导性要求。我国国家公园体制建 设起步较晚, 国家公园教育利用的实践经验和理论探讨相对不足。本文基于Web of Science核心合集数据库相关文 献, 系统回顾了国外国家公园教育利用的研究进展, 并对国内未来研究进行展望。21世纪以来, 国外的国家公园教 育利用研究进展加快, 相关文献多发表在环境科学和地球科学类期刊, 研究内容主要包括教育资源评估以及教育 目的、教育管理、教育成效及其影响因素。国家公园教育资源丰富, 教育价值评估和教育利用适宜性评价是对其 合理利用及保护管理的前提。教育目的主要包括争取保护支持、缓解社区冲突、提供文化及教育服务和防范旅游 伤害, 多样化的教育媒介使用及针对性的教育设计、良好的教育合作共同促进教育成效的最佳实现。教育成效围 绕教育目标分类的认知/意识、情感/态度、行为等维度评估教育受众在教育前后的表现差异, 主要受个体特征与教 育管理两方面因素影响。国外国家公园教育利用研究已初步形成研究内容体系, 并呈现研究区域集中、学科理论 交叉、研究方法趋于定性与定量综合运用、研究内容丰富且涉及领域广等特点。本文提出未来中国应重点加强国 家公园教育资源评价、教育内容体系、教育媒介应用、教育合作与管理、教育成效及其影响因素分析等研究议题。 关键词: 国家公园; 教育功能; 教育价值; 教育利用; 研究进展

\section{Educational use in global national parks: Review and implications}

\author{
Dongjun Chen ${ }^{1,2}$, Linsheng Zhong, ${ }^{1,2}$ \\ 1 Institute of Geographic Sciences and Natural Resources Research, Key Laboratory of Regional Sustainable \\ Development Modeling, Chinese Academy of Sciences, Beijing 100101 \\ 2 University of Chinese Academy of Sciences, Beijing 100049
}

\begin{abstract}
Education is one of the most important functions of national parks, and its use in national parks is underscored by the parks' characteristics of public welfare and national ownership. China's national park system was established only recently. Consequently, the practice and theory of educational use in China's national parks is poorly understood. We analyze the available literature using the core compilation of Web of Science to systematically review educational use in national parks globally and to establish further research directions that can be pursued in China. Research on educational use in national parks has developed rapidly since the 21st century. Most relevant literature was published in environmental science and earth science journals. Research on educational use mainly focus on educational resources assessment, purpose, management, effectiveness, and their influencing factors. National parks are rich in educational resources, and the evaluation of educational potential and suitability are necessary for their appropriate utilization, protection, and management. Education mainly seeks to protection support, buffer community conflicts, provide cultural services, and increase visitor safety. The use of diversified media for education, targeted educational materials, and favorable cooperation are important factors that maximize the effectiveness of education programs. The evaluation of educational effectiveness on the cognition/awareness, emotions/attitudes, and behaviors is mainly influenced by individual characteristics and educational management. International research on educational use of national parks develop interdisciplinary theories, qualitative and quantitative comprehensive applications of research methods, and rich research content across a wide range of fields. Our review suggests that China should strengthen research and evaluation of
\end{abstract}


educational resources, construct a set of educational content systems, use a diversity of educational approaches and media, facilitate educational cooperation and management, evaluate educational effectiveness programs, and analyze additional factors influencing educational use.

Key words: national park; educational function; educational value; educational use; research progress

我国国家公园体制建设起步较晚。2017年，中 共中央办公厅、国务院办公厅印发《建立国家公园 体制总体方案》，指出国家公园的首要功能是自然 生态保护, 同时兼具科研、教育、游息等功能。围 绕国家公园的各项功能定位, 国内学者主要从法律 (刘超, 2019)、政策(刘思源等, 2019)、保护措施(韩 璐等, 2015)、实现模式(李芬等, 2016)及相关技术(刘 某承等, 2019)等方面探讨了国家公园的生态保护功 能优化, 从适宜性(肖练练等, 2019)、经营机制(张朝 枝, 2017)、公共管理(高燕等, 2017)、发展模式(赵西 君和李佐军, 2019)、可持续性(程绍文等, 2013)等方 面讨论了国家公园的游喤利用。

国家公园教育利用是指依托国家公园资源开 展相关教育活动, 以激发民众自然保护意识、增强 民族自豪感等, 体现国家公园的公益性和国家主导 性(陈耀华等, 2014; Lukas et al, 2019)。国家公园建 设在我国虽然刚起步, 但其他类型自然保护地(包 括风景名胜区、水利风景区、自然保护区、地质公 园、湿地公园、森林公园等)结合自身优势已开展一 些特色教育活动, 整体上成效显著, 但同时也存在 教育内容形式单一、缺乏创新和吸引力、评价体系 和立法体系不够健全等问题(梦梦等, 2020)。自然保 护地教育利用的研究始于国内外经验总结及借鉴, 例如香港米埔自然保护区(游云和备启杰, 2004)、日 本演习林制度(徐诗涛等, 2018)、国外青年旅馆模式 (李敏, 2001)及自然保护高等教育(刘晶岗, 2009)等, 对我国自然保护地的教育实践都有重要启示。随着 教育实践的逐渐深入, 国内学者主要从教育解说系 统(张建萍等, 2008)、动力机制(连玉軹, 2011; 李云 珠和黄秀娟, 2013)、教育成效(姜建华, 2014; 夏凌 云等, 2016)、教育模式(陈静杰等, 2017)以及公众对 自然保护地教育功能的感知与认识(严海等, 2010; 何小芉等, 2018)、满意度(张镒等, 2014)等方面探讨 自然保护地教育功能的最佳实现。这些研究为我国 国家公园教育的实践与研究奠定了一定基础。

我国国家公园的教育利用尚处于起步探索阶 段，尽管三江源国家公园、钱江源国家公园等都有
进行相关教育专项规划、探索教育功能价值实现路 径, 但国内仅有少数学者从经验总结介绍、教育解 说、教育体系等方面进行初步的探讨。例如孙燕 (2012)和王辉等(2016)基于美国国家公园教育解说 发展经验，指出我国国家公园应充分认识并因地制 宜地发展教育解说项目; 陈丹和彭蓉(2019)阐述了 我国台湾国家公园的环境教育体系构成, 并总结其 形成基础及作用。国家公园显著的教育成效已得到 充分的科学认证，国家公园已经成为不少国家的重 要教育场所, 在国家教育服务体系中占有重要地位, 例如美国国家公园强调生态保护与教育利用并重, 成为科学、历史、环境和爱国主义教育的重要场所 (国家林业局森林公园管理办公室, 2015)。国外研究 基于环境学、教育学、心理学、社会学等多学科视 角, 主要从教育资源评估、教育管理、教育成效等 方面进行了相关探讨, 为国家公园的教育利用提供 了科学依据。

如何科学合理地对国家公园进行教育利用以 实现其教育功能价值最大化，是当前我国国家公园 体制建设亟需解答的重要问题。本文系统梳理了国 外相关研究成果, 概述国家公园教育利用研究的主 要内容, 总结和评述对国内研究的启示, 以促进国 内国家公园教育利用的相关研究, 为我国国家公园 教育功能实现、国家公园体制建设提供科学参考。

\section{文献来源与概况}

本文使用系统综述方法(Systematic Review)对 相关文献进行系统收集。文献数据来源于Web of Science核心合集, 于 2019年8月 22 日以 “national park”和“education”为主题词进行文献检索, 初步得 到403篇文献。剔除与研究主题不相关文献, 最后整 理得到130篇文献用于本文研究。

基于对上述文献整理, 从文献数量的年际变化 看(图1), 国家公园教育利用研究在21世纪以前进展 缓慢, 在21世纪初呈现加速态势, 2010年后进一步 加快。相关文献主要发表在环境科学与地球科学类 


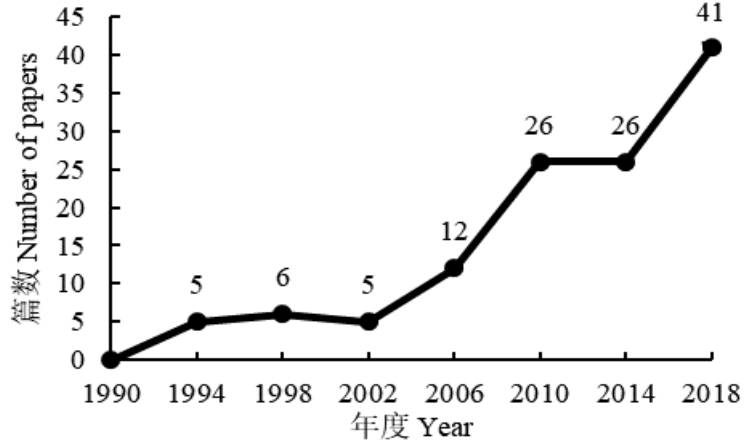

图1 1991-2018年文献数量

Fig. 1 Number of research papers between 1991 and 2018

期刊，期刊多源于美、英等较早进行国家公园体制 建设的国家(表1)。

在研究方法方面, 定性研究中基于参与观察、 问卷访谈等田野调查的描述性分析、案例分析和 SWOT分析使用方法较多, 研究内容主要集中在教 育资源评估、利益相关者态度与教育目的及教育管 理等内容; 定量研究中运用ArcGIS空间分析、相关 分析、数学建模等方法较多, 研究内容主要集中在 教育资源评估、教育成效评估及其影响因素分析。

\section{2 研究内容}

基于对上述文献的分析总结，将国家公园教育 利用的主要研究内容归纳为教育资源评估、教育目 的、教育管理、教育成效及其影响因素 4 个方面。

\section{1 教育资源评估}

国家公园被誉为“没有围墙的大学”，具有丰富 的自然与人文类教育资源，包括地质地貌、动植物、 土著知识、人为景观、宗教与信仰等(表2)。为公众
提供教育机会是国家公园的重要任务与使命(Keiter, 2010)，而教育资源评估是国家公园教育利用的前 提，为其合理利用及保护管理提供科学依据。

教育资源评估包括教育价值评估和教育利用 适宜性评价。教育价值是指教育客体对社会或个体 发展需要的一定满足(王卫东, 1996), 在不同场景及 教育主体间具有主观性与相对性。例如，美国大烟 山既是切罗基人(Cherokees)地方传统的传承载体, 也是公众环境教育的重要素材(Bernbaum, 2006)。主 观性与相对性使得教育价值评估变得困难, 现有研 究多从生态系统服务角度使用支付意愿、价值转 移、协商估值等方法(Sherrouse \& Semmens, 2014; Orchard-Webb et al, 2016; Soy-Massoni et al, 2016) 进行价值量(用货币单位)评估，Hutcheson等(2018) 估算纽约哈德逊河(Hudson River)公园环境教育计 划的年度经济价值约为 60 万美元。在物质量(非货币 单位)评估方面, Mocior和Kruse (2016)在回顾相关 研究基础上，总结了教育价值评估的常用指标，这 些指标包括：不同层面的景观/生态系统特征的稀 有性、完整性/干扰程度/保存水平、过程/现象的代 表性(典型性)、多样性/有趣特征的数量、科学知识 /科学相关性、作为过程示例的有用性(示例)、古地 理价值等。教育价值评估表现了国家公园教育利用 的内在价值，而教育利用适宜性评价则描述了其内 在教育价值实现的外部条件可行性。教育利用适宜 性的定性评价方法以 SWOT分析为主，例如 Nazaruddin (2016)对马来西亚塔曼尼加拉国家公园 (Taman Negara National Park)地质遗迹教育资源的 分析评估。定量评价多采用多指标综合评价方法,

表1 国家公园教育利用研究刊文主要期刊

Table 1 Main journals of published papers on educational use in national parks

\begin{tabular}{llll}
\hline 期刊名称 Journal name & 篇数 No. of published papers & 所在地 Country & JCR类别 Categories of Journal Citation Reports \\
\hline Environmental Management & 8 & 美国 USA & Environmental Sciences \\
Geoheritage & 7 & 德国 Germany & Geosciences \\
Environmental Conservation & 6 & 美国 USA & Environmental Sciences \\
Environmental Education Research & 5 & 英国 UK & Educational Research \\
Journal of Environmental Management & 5 & 英国 UK & Environmental Sciences \\
Wilderness Environmental Medicine & 4 & 美国 USA & Public, Environmental \& Occupational Health \\
American Journal of Primatology & 3 & 美国 USA & Zoology \\
Earth Sciences History & 3 & 美国 USA & Geosciences \\
Journal of Sustainable Tourism & 3 & 英国 UK & Green \& Sustainable Science \& Technology \\
Society Natural Resources & 3 & 美国 USA & Sociology \\
\hline
\end{tabular}


表2 国家公园教育资源案例

Table 2 Cases of education resource in national parks

\begin{tabular}{|c|c|c|c|}
\hline \multicolumn{2}{|c|}{ 类型 Type } & \multirow{2}{*}{$\begin{array}{l}\text { 案例 Case } \\
\text { 岩石, 化石, 喀斯特地貌, 火山湖 } \\
\text { Rock, fossil, karst landform, and volcanic lake }\end{array}$} & \multirow{2}{*}{$\begin{array}{l}\text { 参考文献 Reference } \\
\text { Och \& Graham, 2011; Santucci, 2017; } \\
\text { Pate \& Kerbo, 2017 }\end{array}$} \\
\hline $\begin{array}{l}\text { 自然类 } \\
\text { Natural }\end{array}$ & $\begin{array}{l}\text { 地质地貌 } \\
\text { Geology and landforms }\end{array}$ & & \\
\hline & $\begin{array}{l}\text { 动植物 } \\
\text { Plants and animals }\end{array}$ & $\begin{array}{l}\text { 茧火虫, 森林植被, 宽头蛇 } \\
\text { Fireflies, forest vegetation, and broad-headed snakes }\end{array}$ & $\begin{array}{l}\text { Nyhus et al, 2003; Faust, 2004; Hayes \& } \\
\text { Goldingay, 2012; Tribess et al, 2015; } \\
\text { Ndumeya, 2019 }\end{array}$ \\
\hline \multirow[t]{3}{*}{$\begin{array}{l}\text { 人文类 } \\
\text { Human }\end{array}$} & $\begin{array}{l}\text { 土著知识 } \\
\text { Local knowledge }\end{array}$ & $\begin{array}{l}\text { 地方传统药用知识, 对野生动物的命名 } \\
\text { Knowledge of local traditional medicine, and naming of wild } \\
\text { animals }\end{array}$ & \\
\hline & $\begin{array}{l}\text { 人为景观 } \\
\text { Human landscape }\end{array}$ & $\begin{array}{l}\text { 交通网络, 人为改变的地貌和植物群落, 考古遗迹, 试验站 } \\
\text { Transportation networks, anthropogenc landscapes and plant } \\
\text { communities, archaeological sites, and test stations }\end{array}$ & $\begin{array}{l}\text { Pessis \& Guidon, 2007; Youngs et al, } \\
\text { 2008; Latocha, 2015; Stevens \& Gilson, } \\
\text { 2016 }\end{array}$ \\
\hline & $\begin{array}{l}\text { 宗教与信仰 } \\
\text { Religion and belief }\end{array}$ & $\begin{array}{l}\text { 山的精神与文化含义 } \\
\text { The spiritual and cultural meaning of mountains }\end{array}$ & Bernbaum, 2006 \\
\hline
\end{tabular}

常用指标有: 可进入性、有趣功能/观点的可见性、 教育站点数量/大小、脆弱性、安全性、使用限制、 与其他价值的关联性、解释性潜力等(Brilha, 2016; Mocior \& Kruse, 2016)。

\section{2 教育目的}

概括地说, 国家公园各类教育计划的教育目的 主要包括以下方面:

(1)争取保护支持。尽管国家公园体制被视为自 然保护及社会福祉保障的优秀制度, 但因公众对国 家公园的认知与态度未能达成一致而面临建设或 管理困难(Brooks et al, 1999; Heinen \& Shrivastava, 2009; Tessema et al, 2010)。如园区居民的环境意识 缺乏(Pyrovetsi \& Daoutopoulos, 1999; Khan et al, 2011)、访客的不合理行为(Burgin \& Hardiman, 2012) 都会造成国家公园的环境退化, 一些濒危动植物也 需要更多的关注与保护(Breda et al, 2008)。因此, 旨 在争取公众保护的相关教育计划显得尤为必要。

(2)缓解社区冲突。国家公园不合理的保护管理 政策可能引发社区冲突。过于苛刻的保护政策影响 社区居民生计、过度的旅游开发侵扰社区居民生活 等(高燕等, 2017)。针对社区冲突, 国家公园开展了 相关教育项目以增进社区居民的国家公园认识, 促 进社区居民与国家公园管理者的沟通协商, 保障社 区居民权利。

(3)提供文化及教育服务。在保护典型性、代表 性的自然与人文景观的同时, 国家公园也为公众提 供亲近自然、游悡、教育等社会福利。国家公园实 行相关教育项目以传播国家公园的自然与人文知 识, 提升公众游园体验, 完善科研、教育等文化服
务(Boshoff et al, 2007; Powell \& Ham, 2008; Taff et al, 2014)。文化及教育服务体现了国家公园的公益 性，对公众的国民自豪感提升有重要意义。

(4)防范旅游伤害。随旅游活动的多样化, 不少 游客尝试冒险旅游活动, 源于荒野思想的国家公园 成为其旅游目的地选择之一。Heggie和Heggie (2009) 依据美国国家公园搜救服务的年度报告指出, 徒 步、划船、游泳和攀登是使旅游者受伤害的主要活 动, 山区、湖泊、河流、海洋和沿海是最为常见的 救援环境。国家公园应开展园区游览安全教育, 介 绍伤害发生的物理环境条件以减少旅游伤害 (McIntosh et al, 2012)。

\section{3 教育管理}

\subsection{1 教育方式}

教育媒介与教育设计影响国家公园的教育方 式。教育媒介是指教育过程中承载和传递教育信息 的媒体, 国家公园的教育媒介日益多样化, 包括纸 质媒体(Ferreira, 2012; Guo et al, 2015)、光学投影媒 体和电声媒体(Breuer et al, 2017; Leeds et al, 2017)。 鉴于不同教育媒介特点及教育主体偏好, 国家公园 的教育媒介日趋组合使用。研究表明, 图书、电影 及课程讲解在国家公园教育中的综合使用取得了 良好的教育成效(Bizerril et al, 2011)。教育设计是指 根据教育目的提出具体规划或方案的过程, 对教育 成效有重要影响(Powell \& Ham, 2008)。教育设计应 考虑国家公园资源、教育受众、教育目的等因素。 Mugica和DeLucio (1996)认为, 环境教育设计应结 合访客景观偏好; Santangelo等(2015)基于意大利 Cilento Vallo Di Diano国家公园的地质资源设计了 
适用于不同教育层次(高中师生、大学生、地质旅游 者、导游等)课程教学的教育行程, 并阐明各教育站 点的重点教育内容。

\subsection{2 教育合作}

国家公园的教育利用涉及多方利益群体, 其教 育管理举措应争取多方支持与合作, 包括社区、学 校、科研单位、政府等。在教育合作中, 国家公园 是教育场地与教育资源的提供者，政府制定相关政 策并提供支持(Stevens \& Gilson, 2016); 科研机构 依托国家公园资源开展相关研究, 并与社区、教育 机构共同实施相关教育项目(Kling \& Hopkins, 2015; Clayborn et al, 2017)。社区在教育合作中的角色较 为特殊, 当教育目的是为了争取保护支持或缓解社 区冲突时, 社区成为教育受众; 当教育目的是为了 提供文化及教育服务时，社区成为文化及教育服务 方。良好的教育合作不仅促进国家公园生态保护与 科研教育功能的发挥, 也有利于当地的经济社会发 展。对波兰国家公园自然保护功能与旅游功能关系 的研究指出, 市政当局与国家公园之间的良好合作 不仅保护了自然生态, 也促进了区域的经济发展 (Kulczyk-Dynowska \& Bal-Domanska, 2019)。

\section{4 教育成效及其影响因素}

作为反馈环节, 教育成效通过受众在教育前后 某方面的表现差异来体现, 教育成效评估为国家公 园的教育目标实现及教育成效最优化提供科学依 据。围绕教育目标分类的认知/意识、情感/态度、 行为等维度, 相关研究多从单一或多个维度评估国 家公园的教育成效(表 3)。例如 Papageorgiou (2001)
以访客对国家公园相关知识的掌握(即认知)评估了 国家公园的环境教育成效，指出环境教育可在短期 内增进访客的国家公园知识并长期促进其保护态 度的转变; Gore 等(2006)以与熊相关投诉(即行为) 数量评估了旨在减少人熊冲突教育计划的成效, 并 建议继续实施相关教育计划以保护和管理熊类。一 般而言，认知/意识、情感/态度、行为三者呈递进关 系, 即对国家公园教育的认知/意识越多/强, 则情 感/态度越积极，相关的积极行为越容易发生 (Papageorgiou, 2001; Hovardas \& Poirazidis, 2006; Powell \& Ham, 2008; Kling \& Hopkins, 2015)。

影响国家公园教育成效的因素可归为个体特 征与教育管理两个方面。个体特征包括性别、年龄、 受教育程度、与国家公园的利益关系等。研究表明, 受过高等教育者通常能更好记住教育计划信息 (Breuer \& Mavinga, 2010; Keane et al, 2011)，男性、 年龄较大者表现出更高的知识水平(Keane et al, 2011), 国家公园教育的利益获得者表现出更好的 教育成效(Western et al, 2019)。教育管理方面的媒介 选用及组合(Bizerril et al, 2011)、教育分工协作以及 教育设计的合理性(Santangelo et al, 2015)直接影响 教育成效。例如实验证明, 视频和戏剧在保护大猩 猩教育计划中的使用显著提高和改善了周边村民 的知识水平和态度(Breuer et al, 2017)。

\section{3 研究评述}

根据以上研究内容梳理可知, 国外国家公园教 育利用研究的内容体系已初步形成(图2)。围绕国家

表3 教育成效评估指标设置

Table 3 Indicators setting for educational effectiveness evaluation

\begin{tabular}{ll}
\hline $\begin{array}{l}\text { 教育目的 } \\
\text { Educational purpose }\end{array}$ & $\begin{array}{l}\text { 参考文献 } \\
\text { References }\end{array}$ \\
\hline $\begin{array}{l}\text { 争取保护支持 } \\
\text { Drum up protection support }\end{array}$ & $\begin{array}{l}\text { Papageorgiou, 2001; } \\
\text { Powell et al, 2009; } \\
\text { Lee et al, 2015 }\end{array}$ \\
& \\
缓解社区冲突 & \\
Buffer community conflicts & $\begin{array}{l}\text { Gore et al, 2006; } \\
\text { Moorman, 2006 }\end{array}$ \\
提供文化及教育服务 & \\
Provide cultural and & $\begin{array}{l}\text { Adara, 1996; Boshoff } \\
\text { et al, 2007 }\end{array}$
\end{tabular}

教育成效评估指标及维度

Indicators and dimensions of educational effectiveness evaluation

对国家公园相关知识的掌握(认知); 环境责任行为(行为); 国家公园认知、对 园区管理的态度及环境行为(认知、态度、行为)

Master knowledge of national park (awareness); environmental responsibility behavior (behavior); national park cognition, attitude to park management and environmental behavior (awareness, attitude and behavior)

与熊相关的投诉(行为); 对生态知识的了解、狩猎行为(认知、行为) Complaints related to bears (behavior); knowledge of ecology and hunting behavior(awareness and behavior)

旅游满意度(情感/态度); 教师在环境教育方面的意识、知识、技能、行动和 承诺/参与(认知/意识、情感/态度、行为)

Travel satisfaction (emotions); teachers' awareness, knowledge, skills, actions and commitment/participation in environmental education (cognition/awareness, emotions/attitudes, behaviors) 


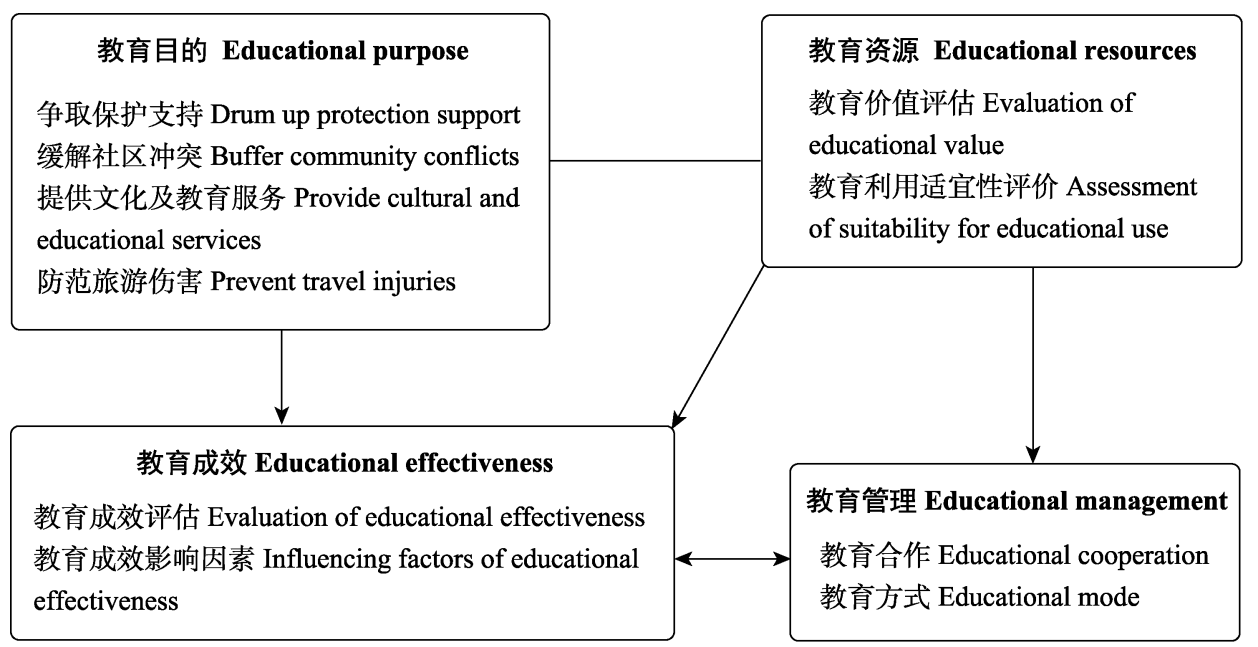

图2 国家公园教育利用研究内容体系

Fig. 2 Content system of educational use in national park research

公园教育利用问题, 相关研究主要评估国家公园教 育资源、设定教育目的、制定教育计划、评估教育 成效并据此改进教育管理措施以实现国家公园教 育服务功能最优化。总体而言，国外国家公园教育 利用研究体现出以下特征:

(1)研究区域集中在国家公园体制建设较早的 国家，主要有美国(61篇)、英国(10篇)、澳大利亚(9 篇)、南非(9篇)、德国(5篇)等。随着国家公园体制 在世界范围内的传播与推广及其教育利用的不断 深入, 研究区域将进一步扩大。

(2)研究理论主要涉及心理学、教育学、社会学 等学科。随公众教育需求的日益增长及多样化, 国 家公园的教育利用目的、利用方式、媒介使用及教 育受众等越加丰富, 更多学科理论被应用于相关研 究, 学科交叉性和集成性特征进一步显现。

(3)研究方法趋于定性与定量方法的综合运用。 随国家公园教育利用实践与研究的深入, 对研究问 题描述和解释的准确性及合理性以及研究结论的 科学性及实用性要求不断提高, 研究方法也从定性 研究为主转向定性与定量研究方法相结合。

(4)研究内容丰富、涉及领域较广, 初步形成体 系, 但需要进一步完善, 包括: 国家公园教育内容 体系研究不足; 教育资源的价值评估对各类教育需 求的满足有欠考虑, 且多限于定性研究; 教育成效 评估忽略了时间因素, 即教育时长以及教育成效的 持续性; 教育管理研究未能充分结合社会发展条件, 考虑在不同文化、科技、制度等背景下的管理创新。

\section{对中国国家公园教育利用研究的}

2019年，中共中央办公厅、国务院办公厅印发 《建立以国家公园为主体的自然保护地体系的指 导意见》，从总体要求、管理体制、保护措施等方 面提出相关意见以加快建立以国家公园为主体的 自然保护地体系; 同时，国家林业和草原局发布 《充分发挥各类保护地社会功能, 大力开展自然教 育工作的通知》，凸显了自然保护地教育利用的重 要性。在中国生态文明建设大力推进及国民教育需 求日益增长的时代背景下, 自然保护地的教育利用 将进一步加强, 其教育功能价值将进一步凸显, 自 然保护地体系主体定位的国家公园的教育利用势 在必行。应充分借鉴国外研究成果, 结合我国自然 保护地教育利用实践与研究现状, 加强中国国家公 园教育利用的理论研究, 构建并完善国家公园教育 利用研究内容体系, 为国家公园体制建设、国家公 园教育服务功能的实现提供参考。国内国家公园教 育利用的后续研究可重点关注以下议题:

(1)教育资源评价研究。从内在教育价值-外在 利用适宜性综合评价国家公园教育资源, 为国家公 园教育资源开发提供科学依据。充分考虑价值的相 对性, 结合教育目的、教育主体特征及具体教育场 景, 尝试运用经济学、社会学、心理学等学科理论 对国家公园各类教育资源进行定量与定性综合的 教育价值评估; 综合考虑自然承载力、社会环境、 相关设施等外在条件, 分析国家公园各类资源的教 
育利用适宜性。

(2)教育内容体系研究。从要素、结构、构建理 论及方法完善国家公园教育内容体系研究。对教育 内容的研究不应局限于环境教育或科普教育, 国家 公园在地方感、民族自豪感、国家认同等方面的情 感教育作用也值得重视。可尝试基于教育需求、教 育目的、教育资源现状等构建国家公园教育内容体 系, 从教育学、心理学、社会学角度提出教育内容 体系构建的理论与方法。

(3)教育媒介应用研究。分析各类媒介在国家公 园教育实践中的优劣性, 为国家公园教育媒介使用 提供科学参考。教育媒介形态经历了教具化、多媒 体化、智能化阶段, 并呈现虚拟化的演变态势(徐金金 金金, 2015)。可采用实验法比较各种媒介在国家公园 教育中的成效; 结合相关实践案例, 分析在虚拟现 实 (Virtual Reality, VR)、增强现实 (Augmented Reality, AR)、5G等技术背景下的国家公园教育媒介 应用适宜性与创新性。

(4)教育合作与管理研究。探讨国家公园教育合 作机制与管理创新, 为国家公园教育利用的可持续 发展提供保障。国家公园教育利用涉及多方利益群 体，应综合分析社区、教育主体、教育机构等多方 利益诉求; 结合相关案例分析国内外国家公园合作 管理的成功经验，如美国自然地标计划(Eggleston \& Connors, 2017), 并结合我国具体国情分析国外 经验的适用性; 基于利益群体社会关系及国内外相 关经验，探讨合作管理创新机制。

(5)教育成效评估及影响因素研究。评估国家公 园教育成效并分析其影响因素, 为实现教育目的及 提升教育成效提供科学依据。结合教育学、心理学、 社会学等学科理论，根据教育目标构建评估体系、 分析国家公园教育成效, 并进一步分析影响教育成 效的相关因素，探讨各因素之间的相互作用关系。

\section{参考文献}

Adara OA (1996) Impact of an outdoor educational strategy on teacher profile in environmental education. International Journal of Educational Development, 16, 309-317.

Bernbaum E (2006) Sacred mountains: Themes and teachings. Mountain Research and Development, 26, 304-309.

Bizerril MXA, Soares CC, Santos JP (2011) Linking community communication to conservation of the maned wolf in central Brazil. Environmental Education Research, 17,
815-827.

Boshoff AF, Landman M, Kerley GIH, Bradfield M (2007) Profiles, views and observations of visitors to the Addo Elephant National Park, Eastern Cape, South Africa. South African Journal of Wildlife Research, 37, 189-196.

Breda G, Faria-Correa MA, Balbueno RA, Hartz SM (2008) Occurrence of the Puma concolor (Linnaeus, 1771) in the metropolitan region of Porto Alegre, RS, Brazil. Natureza \& Conservacao, 6, 136-152.

Breuer T, Mavinga FB (2010) Education for the conservation of Great Apes and other wildlife in Northern Congo-The importance of nature clubs. American Journal of Primatology, 72, 454-461.

Breuer T, Mavinga FB, Evans R, Lukas KE (2017) Using video and theater to increase knowledge and change attitudes - Why are gorillas important to the world and to Congo? American Journal of Primatology, 79, 1-10.

Brilha J (2016) Inventory and quantitative assessment of geosites and geodiversity sites: A review. Geoheritage, 8, 119-134.

Brooks JJ, Warren RJ, Nelms MG, Tarrant MA (1999) Visitor attitudes toward and knowledge of restored bobcats on Cumberland Island National Seashore, Georgia. Wildlife Society Bulletin, 27, 1089-1097.

Burgin S, Hardiman N (2012) Extreme sports in natural areas: Looming disaster or a catalyst for a paradigm shift in land use planning? Journal of Environmental Planning and Management, 55, 921-940.

Chen D, Peng R (2019) Analysis on environmental education system in China's Taiwan national parks: Take Jinmen National Park as an example. China Forest Products Industry, 46(5), 62-64. (in Chinese with English abstract) [陈丹, 彭蓉 (2019) 台湾地区国家公园环境教育体系浅析以金门国家公园为例. 林产工业, 46(5), 62-64.]

Chen JJ, Wang LL, Zheng YF, Ling MS, Wu SD (2017) Research on the innovation of environmental education model in nature reserves under the national park concept: Taking Longqishan National Nature Reserve in Fujian Province as an example. Fujian Tribune, (12), 196-201. (in Chinese) [陈静杰, 王莉莉, 郑逸凡, 林明水, 伍世代 (2017) 国家公园理念下自然保护区环境教育模式创新研 究——以福建省龙栖山国家自然保护区为例. 福建论坛, (12), 196-201.]

Chen YH, Huang D, Yan SQ (2014) Discussions on public welfare, state dominance and scientificity of national park. Scientia Geographica Sinica, 34, 257-264. (in Chinese) [陈 耀华，黄丹，颜思琦 (2014) 论国家公园的公益性、国家 主导性和科学性. 地理科学, 34, 257-264.]

Cheng SW, Zhang J, Hu J Xu F-F (2013) Comparative evaluation of tourism sustainability between national parks in the UK and China: A case study of Jiuzhaigou National Park. Human Geography, 28(2), 20-26. (in Chinese) [程绍 文, 张捷, 胡静, Xu Fei-fei (2013) 中英国家公园旅游可 持续性比较研究—以中国九寨沟和英国新森林国家公 
园为例. 人文地理, 28(2), 20-26.]

Clayborn J, Koptur S, O’Brien G, Whelan KRT (2017) The Schaus Swallowtail Habitat Enhancement Project: An applied service-learning project continuum from Biscayne National Park to Miami-Dade County public schools. Southeastern Naturalist, 16, 26-46.

Eggleston H, Connors T (2017) Shared conservation of America's geological heritage through the Natural Landmarks Program. Earth Sciences History, 36, 190-196.

Faust LF (2004) Fireflies as a catalyst for science education. Integrative and Comparative Biology, 44, 264-265.

Ferreira S (2012) Moulding urban children towards environmental stewardship: The Table Mountain National Park experience. Environmental Education Research, 18, 251-270.

Forest Park Management Office of State Forestry Administration, China (2015) A Comparative Study of National Park System. China Forestry Publishing House, Beijing. (in Chinese) [国家林业局森林公园管理办公室 (2015) 国家 公园体制比较研究. 中国林业出版社, 北京.]

Gao Y, Deng Y, Zhang H, Wang JY, Liang B (2017) Community conflicts of the national park overseas: Performance, tracing origins and enlightenment. Tourism Tribune, 32(1), 111-122. (in Chinese) [高燕, 邓毅, 张浩, 王建英, 梁滨 (2017) 境外国家公园社区管理冲突: 表 现、溯源及启示. 旅游学刊, 32(1), 111-122.]

Gore ML, Knuth BA, Curtis PD, Shanahan JE (2006) Education programs for reducing American black bear-human conflict: Indicators of success? Ursus, 17, 75-80.

Guo T, Smith JW, Leung YF, Seekamp E, Moore RL (2015) Determinants of responsible hiking behavior: Results from a stated choice experiment. Environmental Management, 56, 765-776.

Han L, Wu HM, Cheng BD, Weng YL (2015) South Africa's biodiversity conservation and its enlightenment to China: A case study of Kruger National Park. World Forestry Research, 28(3), 75-79. (in Chinese with English abstract) [韩璐, 吴红梅, 程宝栋, 温亚利 (2015) 南非生物多样性 保护措施及启示一以南非克鲁格国家公园为例. 世界 林业研究, 28(3), 75-79.]

Hayes IF, Goldingay RL (2012) Visitors' knowledge of the broad-headed snake in Royal National Park. Proceedings of the Linnean Society of New South Wales, 134, B135-B146.

He XQ, Li CN, Xu JJ (2018) The features of tourists perception of popular science education in Mount Longhu Global Geopark. Journal of Arid Resources and Environment, 32, 202-208. (in Chinese) [何小芉，李超男，许甲甲 (2018) 龙虎山世界地质公园科普教育的游客感知特征研究. 干 旱区资源与环境, 32, 202-208.]

Heggie TW, Heggie TM (2009) Search and rescue trends associated with recreational travel in US national parks. Journal of Travel Medicine, 16, 23-27.

Heinen JT, Shrivastava RJ (2009) An analysis of conservation attitudes and awareness around Kaziranga National Park, Assam, India: Implications for conservation and development. Population and Environment, 30, 261-274.

Hovardas T, Poirazidis K (2006) Evaluation of the environmentalist dimension of ecotourism at the Dadia Forest Reserve (Greece). Environmental Management, 38, 810-822.

Hutcheson W, Hoagland P, Jin D (2018) Valuing environmental education as a cultural ecosystem service at Hudson River Park. Ecosystem Services, 31, 387-394.

Jiang JH (2014) An empirical study on the effect evaluation of ecotourism environmental education. Travel Overview, (20), 292. (in Chinese) [姜建华 (2014) 生态旅游环境教育效果 评价实证研究. 旅游纵览, (20), 292.]

Keane A, Ramarolahy AA, Jones JPG, Milner-Gulland EJ (2011) Evidence for the effects of environmental engagement and education on knowledge of wildlife laws in Madagascar. Conservation Letters, 4, 55-63.

Keiter RB (2010) The national park system: Visions for tomorrow. Natural Resources Journal, 50, 71-110.

Khan B, Abdukadir A, Qureshi R, Mustafa G (2011) Medicinal uses of plants by the inhabitants of Khunjerab Park, Gilgit, Parkistan. Parkistan Journal of Botany, 43, 2301-2310.

Kling KJ, Hopkins ME (2015) Are we making the grade? Practices and reported efficacy measures of primate conservation education programs. American Journal of Primatology, 77, 434-448.

Kulczyk-Dynowska A, Bal-Domanska B (2019) The national parks in the context of tourist function development in territorially linked municipalities in Poland. Sustainability, 11, 1-22.

Latocha A (2015) Past human activities recorded in the landscape: A case study from the Glenveagh National Park, Ireland. Landscape Research, 40, 338-358.

Lee TH, Jan FH, Huang GW (2015) The influence of recreation experiences on environmentally responsible behavior: The case of Liuqiu Island, Taiwan. Journal of Sustainable Tourism, 23, 947-967.

Leeds A, Lukas KE, Kendall CJ, Slavin MA, Ross EA, Robbins MM, van Weeghel D, Bergl RA (2017) Evaluating the effect of a year-long film focused environmental education program on Ugandan student knowledge of and attitudes toward great apes. American Journal of Primatology, 79, $1-9$.

Li C (2019) Legal expression of the natural reserve system with national park as the main body. Journal of Jishou University (Social Sciences), 40(5), 81-92. (in Chinese with English abstract) [刘超 (2019) 以国家公园为主体的自然保护地 体系的法律表达. 吉首大学学报(社会科学版), 40(5), 81-92.]

Li F, Zhang LB, Li DQ (2016) National park: New pattern for ecological and environmental protection in the Three-River Headwaters Area. Ecological Economy, 32(1), 191-193. (in Chinese with English abstract) [李芬, 张林波, 李岱青 (2016) 国家公园: 三江源地区生态环境保护新模式. 生 


\section{态经济, 32(1), 191-193.]}

Li M (2001) Youth hostel and eco-tourism: An analysis of applicability of the mode of youth hostel in nature reserves in China. Journal of Social Science of Hunan Normal University, (1), 38-42. (in Chinese) [李敏 (2001) 青年旅 馆与生态旅游一一青年旅馆模式在我国自然保护区的适 用性分析. 湖南师范大学社会科学学报, (1), 38-42.]

Li YZ, Huang XJ (2013) Analysis on environmental education mechanism of forest park and research on the strategies for developing the mechanism. Issues of Forestry Economics, 33, 373-378. (in Chinese with English abstract) [李云珠, 黄秀娟 (2013) 森林公园环境教育机制分析及策略研究. 林业经济问题, 33, 373-378.]

Lian YR (2011) An empirical study of environment education scenic areas. Tourism Forum, 4(5), 107-112. (in Chinese) [连玉銮 (2011) 生态旅游景区环境教育实证研究—— 四川省为例. 旅游论坛, 4(5), 107-112.]

Liu JL (2009) Comparison of higher education on nature on servation among the United States, Germany and China. World Forestry Research, 22(3), 64-68. (in Chinese with English abstract) [刘晶岗 (2009) 中美德三国自然保护高 等教育比较. 世界林业研究, 22(3), 64-68.]

Liu MC, Wang JR, Liu WW, Yang L, Sang WG (2019) Policy framework and key technologies of ecological protection compensation to national park. Acta Ecologica Sinica, 39, 1330-1337. (in Chinese) [刘某承, 王佳然, 刘伟玮, 杨伦, 桑卫国 (2019) 国家公园生态保护补偿的政策框架及其 关键技术. 生态学报, 39, 1330-1337.]

Liu SY, Tang XL, Sun YF (2019) An overview of forest ecological conservation system in natural protected areas of developed countries. World Forestry Research, 32(3), 1-6. (in Chinese with English abstract) [刘思源, 唐晓岚, 孙彦 斐 (2019) 发达国家自然保护地森林资源生态保育制度 综述. 世界林业研究, 32(3), 1-6.]

Lukas KE, Leeds A, Slavin MA, Tinka J, Kendall CJ (2019) Impact of teacher training in conservation education on student learning in primary schools adjacent to Kibale National Park, Uganda. Oryx, 53, 497-504.

McIntosh SE, Campbell A, Weber D, Dow J, Joy E, Grissom CK (2012) Mountaineering medical events and trauma on Denali, 1992-2011. High Altitude Medicine \& Biology, 13, 275-280.

Meng M, Liu X, Zhao YN, Zhou XH (2020) Analysis of practice and research status of environmental education related to protected areas in China. World Forestry Research, 33(2), 1-7. (in Chinese with English abstract) [梦梦, 刘金金, 赵英 男, 周学红 (2020) 自然保护地环境教育实践与研究现 状. 世界林业研究, 33(2), 1-7.]

Mocior E, Kruse M (2016) Educational values and services of ecosystems and landscapes: An overview. Ecological Indicators, 60, 137-151.

Moorman RS (2006) Benefits of local residents visiting La Selva Biological Station, Costa Rica. Environmental Conservation, 33, 89-99.
Mugica M, DeLucio JV (1996) The role of on-site experience on landscape preferences: A case study at Donana National Park (Spain). Journal of Environmental Management, 47, 229-239.

Nazaruddin DA (2016) Geoheritage from the remote rainforest: Hidden treasures in the upstream of the Pertang River, Taman Negara Kuala Koh (National Park), Kelantan, Malaysia. Environmental Earth Sciences, 75, 1201-1212.

Ndumeya N (2019) Nature, conservation and conflict in Eastern Zimbabwe: Chirinda Forest, 1980-2000. Journal of Southern African Studies, 45, 253-271.

Nyhus PJ, Sumianto, Tilson R (2003) Wildlife knowledge among migrants in southern Sumatra, Indonesia: Implications for conservation. Environmental Conservation, 30, 192-199.

Och DJ, Graham IT (2011) Preservation of the rocky beach blueschist-eclogite outcrop, Port Macquarie, NSW as a geoheritage reserve. Proceedings of the Linnean Society of New South Wales, 132, 109-114.

Orchard-Webb J, Kenter JO, Bryce R, Church A (2016) Deliberative democratic monetary valuation to implement the ecosystem approach. Ecosystem Services, 21, 308-318.

Papageorgiou K (2001) A combined park management framework based on regulatory and behavioral strategies: Use-of visitors' knowledge to assess effectiveness. Environmental Management, 28, 61-73.

Pate DL, Kerbo RC (2017) Understanding and preserving caves and karst landscapes. Earth Sciences History, 36, 318-336.

Pessis AM, Guidon N (2007) Serra da Capivara National Park, Brazil: Cultural heritage and society. World Archaeology, 39, 406-416.

Powell RB, Ham SH (2008) Can ecotourism interpretation really lead to pro-conservation knowledge, attitudes and behaviour? Evidence from the Galapagos Islands. Journal of Sustainable Tourism, 16, 467-489.

Powell RB, Kellert SR, Ham SH (2009) Interactional theory and the sustainable nature-based tourism experience. Society \& Natural Resources, 22, 761-776.

Pyrovetsi M, Daoutopoulos G (1999) Farmers' needs for nature conservation education in Greece. Journal of Environmental Management, 56, 147-157.

Santangelo N, Romano P, Santo A (2015) Geo-itineraries in the Cilento Vallo di Diano Geopark: A tool for tourism development in Southern Italy. Geoheritage, 7, 319-335.

Santucci VL (2017) Preserving fossils in the national parks: A history. Earth Sciences History, 36, 245-285.

Sherrouse BC, Semmens DJ (2014) Validating a method for transferring social values of ecosystem services between public lands in the Rocky Mountain region. Ecosystem Services, 8, 166-177.

Soy-Massoni E, Langemeyer J, Varga D, Saez M, Pinto J (2016) The importance of ecosystem services in coastal agricultural landscapes: Case study from the Costa Brava, Catalonia. Ecosystem Services, 17, 43-52. 
Stevens MT, Gilson GG (2016) An exploration of field-station partnerships: University-operated field stations located in US national parks. BioScience, 66, 693-701.

Sun Y (2012) The rise of interpretation in US national parks and its inspirations. Chinese Landscape Architecture, 28(6), 110-112. (in Chinese with English abstract) [孙燕 (2012) 美国国家公园解说的兴起及启示. 中国园林, 28(6), 110-112.]

Taff D, Newman P, Lawson SR, Bright A, Marin L, Gibson A, Archie T (2014) The role of messaging on acceptability of military aircraft sounds in Sequoia National Park. Applied Acoustics, 84, 122-128.

Tessema ME, Lilieholm RJ, Ashenafi ZT, Leader-Williams N (2010) Community attitudes toward wildlife and protected areas in Ethiopia. Society \& Natural Resources, 23, 489-506.

Tribess B, Pintarelli GM, Bini LA, Camargo A, Funez LA, de Gasper AL, Bertarello Zeni AL (2015) Ethnobotanical study of plants used for therapeutic purposes in the Atlantic Forest region, Southern Brazil. Journal of Ethnopharmacology, 164, 136-146.

Wang H, Zhang JC, Liu XY, Wang L (2016) Interpretation and education in the US national park: A case study of the Theodore Roosevelt National Park. Tourism Tribune, 31(5), 119-126. (in Chinese) [王辉, 张佳琛, 刘小宇, 王亮 (2016) 美国国家公园的解说与教育服务研究——以西奥 多・罗斯福国家公园为例. 旅游学刊, 31(5), 119-126.]

Wang WD (1996) The historical investigation and theoretical analysis of the concept of educational value. Journal of Beijing Normal University (Social Sciences), (2), 29-35. (in Chinese) [王卫东 (1996) 教育价值概念的历史考察与理 论分析. 北京师范大学学报(社会科学版), (2), 29-35.]

Weichenthal L, Allen J, Davis KP, Campagne D, Snowden B, Hughes S (2011) Lightning safety awareness of visitors in three California national parks. Wilderness \& Environmental Medicine, 22, 257-261.

Western G, Macdonald DW, Loveridge AJ, Dickman AJ (2019) Creating landscapes of coexistence: Do conservation interventions promote tolerance of lions in human-dominated landscapes? Conservation \& Society, 17, 204-217.

Xia LY, Yu HX, Wang HC, Ju YF (2016) Impact of eco-education on visitor's environmental behavior intentions in Wetland Park: A case study of 5 Wetland Parks in Harbin. Wetland Science, 14(1), 72-81. (in Chinese with English abstract) [夏凌云, 于洪贤, 王洪成, 鞠永富 (2016) 湿地 公园生态教育对游客环境行为倾向的影响——哈尔滨 市5个湿地公园为例. 湿地科学, 14(1), 72-81.]

Xiao LL, Zhong LS, Yu H, Zhou R (2019) Assessment of recreational use suitability of Qianjiangyuan National Park pilot under the zoning constraints. Acta Ecologica Sinica, 39, 1375-1384. (in Chinese with English abstract) [肖练练, 钟林生, 虞虎, 周睿 (2019) 功能约束条件下的钱江源国
家公园体制试点区游憩利用适宜性评价研究. 生态学报, 39, 1375-1384.]

Xu ST, Song XQ, Ling P, Chen YJ, Ren MX (2018) The University Forests of Japan and implications for biodiversity conservation and national park development in China. Biodiversity Science, 26, 96-104. (in Chinese with English abstract) [徐诗涛, 宋希强, 凌鹏, 陈元君, 任明迅 (2018) 日本演习林制度对中国生物多样性保护与国家公园建设 的启示. 生物多样性, 26, 96-104.]

Xu XX (2015) New trends in the development of educational media forms. New Media Research, 1(1), 122-123, 107. (in Chinese) [徐金金金金 (2015) 教育媒介形态发展新趋势. 新 媒体研究, 1(1), 122-123, 107.]

Yan H, Chen J, He H (2010) Preliminary investigation on function recognition and image perception in public upon botanical gardens. Biodiversity Science, 18, 516-522. (in Chinese with English abstract) [严海, 陈进, 贺赫 (2010) 公众对植物园功能定位和形象认知的初步调查. 生物多 样性, 18, 516-522.]

You Y, Chu QJ (2004) Environment education in Maipo Nature Reserve, Hong Kong. Biology Teaching, 29(7), 42-44. (in Chinese) [游云, 备启杰 (2004) 香港米埔自然 保护区的环境教育. 生物学教学, 29(7), 42-44.]

Youngs YL, White DD, Wodrich JA (2008) Transportation systems as cultural landscapes in National Parks: The case of Yosemite. Society \& Natural Resources, 21, 797-811.

Zhang CZ (2017) Reform of management mechanism of national parks based on tourism. Environment Protection, 45(14), 28-33. (in Chinese) [张朝枝 (2017) 基于旅游视角 的国家公园经营机制改革. 环境保护, 45(14), 28-33.]

Zhang JP, Liang YY, Zhu L (2008) An analysis of problems in environmental promotion system in Baihua Mountain Nature Reserve: A case study with countermeasures. Journal of Beijing Jiaotong University (Social Sciences Edition), (4), 108-112. (in Chinese) [张建萍, 梁莺莺, 朱亮 (2008) 百花山自然保护区环境解说系统问题分析及对策. 北京 交通大学学报(社会科学版), (4), 108-112.]

Zhang Y, Su XW, Huang DY (2014) Satisfaction of Hong Kong residents on ecological education function of Hong Kong wetland park and its influence factors. Wetland Science, 12, 656-661. (in Chinese with English abstract) [张 镒, 苏欣慰, 黄冬盈 (2014) 香港居民对湿地公园生态教 化功能的满意度及其影响因素研究. 湿地科学, 12 , 656-661.]

Zhao XJ, Li ZJ (2019) Research on tourism development model under national park management system. Jianghuai Tribune, (1), 31-36. (in Chinese) [赵西君, 李佐军 (2019) 国家公园管理体制下的旅游发展模式研究. 江淮论坛, (1), 31-36.]

(责任编委: 李俊生 责任编辑: 时意专) 